\title{
Relationship between Shift Work and the Risk of Prostate Cancer: An Evidence Base Case Report
}

\author{
Irwan Suhadi ${ }^{1}$, Indah Widyahening ${ }^{2}$, Muhammad Ilyas ${ }^{3}$ \\ ${ }^{1}$ Post Graduate of Occupational Medicine Specialist Program, Faculty of Medicine, Universitas Indonesia, \\ Jakarta, Indonesia. \\ ${ }^{2}$ Department of Community Medicine, Faculty of Medicine, Universitas Indonesia, Jakarta, Indonesia \\ ${ }^{3}$ Department of Occupational Medicine, Faculty of Medicine, Universitas Indonesia, Jakarta, Indonesia
}

First and Corresponding Author: Irwan Suhadi

E-mail: irwan.suhadi.83@gmail.com

\begin{abstract}
Prostate cancer has been associated with jobs that involve some degree of work at night. In 2007, the International Agency for Research on Cancer (IARC) concluded that shift work involving circadian disruption was probably carcinogenic in humans. Exposure to artificial LAN (Light at Night) suppresses pineal melatonin secretion and subsequently leads to an increase of sex hormones, which in turn could increase the susceptibility to hormonedependent cancers. Disruption of the circadian rhythm regulated by several clock genes controlling apoptosis and cell proliferation, repeated phase shifting leading to internal desynchronisation and defects in the regulation of the circadian cell cycle, and also sleep deprivation alters immune function.

In this case, the authors assessed the relationship between workers in a manufacture company who had worked shift work for 30 years and an increased risk of prostate cancer. This case takes evidence base from several journals that support this hypothesis while doing a critical appraisal to determine its validity and applicability.
\end{abstract}

Keywords: Shift work, Prostate cancer

\begin{abstract}
Abstrak
Kanker prostat diketahui berhubungan dengan pekerjaan yang melibatkan kerja shift. Pada tahun 2007, International Agency for Research on Cancer (IARC) menyatakan bahwa kerja shift dengan disrupsi sirkadian menyebabkan kemungkinan kanker pada manusia. Pajanan terhadap LAN (Light at Night) menekan sekresei melatonin pineal dan menstimulasi peningkatan hormon sex yang pada gilirannya dapat meningkatkan kerentanan terhadap kanker yang bergantung pada hormon. Kasus disini akan menilai bagaimana hubungan antara pekerja shift suatu manufaktur yang telah bekerja 30 tahun dengan peningkatan risiko kanker prostat melalui beberapa telaah jurnal kritis untuk menilai validitas dan aplikabilitasnya. Dari ketiga jurnal yang ditelaah adalah valid dan aplikatif. Sebuah systematic review dan meta-analysis oleh Mancio J.dkk tahun 2018 adanya peningkatan yang signifikan antara kanker prostat dengan rotasi kerja gilir. Begitu pula dengan Behrens T.dkk tahun 2017. Namun, studi kohort Torbjrn A.dkk tahun 2017 menilai tidak ada hubungan kanker prostat dengan durasi kerja malam. Perbedaan ini mungkin karena kurangnya pengukuran pajanan, dan perbedaan dalam jenis kovariat yang disesuaikan untuk kelompok pekerjaan heterogen yang terlibat.
\end{abstract}

Kata kunci: kerja gilir, kanker prostat, telaah jurnal 


\section{Introduction}

Prostate cancer has been associated with jobs that involve some degree of work at night. ${ }^{1}$ Prostate cancer is the most common cancer and the second leading cause of cancer-related deaths among men. ${ }^{2}$ Prostate cancer is the most common cancer in men in industrialised countries with more than 1.000.000 cases diagnosed worldwide in 2012. Despite its high incidence, only age, ethnic origin and family history of prostate cancer are well-established risk factors. Among those factors, a possible role of circadian disruption related to night work in prostate cancer risk has emerged, especially since the publication of the International Agency for Research on Cancer (IARC) that classified in 2007 'shift work leading to a disruption of circadian rhythm' as probably carcinogenic to humans. ${ }^{3}$ Although much of the research regarding the carcinogenicity of circadian disruption focused on breast cancer an increasing body of evidence has emerged associating prostate cancer with shift work. ${ }^{4}$

One of the major behavioral consequences of night shift work is displacement of the sleep-wake cycle, which results in shift workers having difficulty falling asleep and staying asleep when they attempt to sleep during the day. Short night-time sleep has been shown to be associated with an increased risk of prostate cancer. $^{5}$

Possible mechanisms linking shift work and cancer center around the "lightat-night" (LAN) hypothesis, which postulates that exposure to artificial LAN suppresses pineal melatonin secretion and subsequently leads to an increase of sex hormones, which in turn could increase the susceptibility to hormone-dependent cancers. Also, anti-proliferative effects of melatonin that could influence tumor origin and progression for prostate cancer cells. ${ }^{4}$

Several biological mechanisms for how circadian disruption may be related to cancer have been hypothesised, among which: (1) exposure to light at night that suppresses the nocturnal peak of melatonin and its associated anticarcinogenic effects; (2) disruption of the circadian rhythm regulated by several clock genes controlling apoptosis and cell proliferation; (3) repeated phase shifting leading to internal desynchronisation and defects in the regulation of the circadian cell cycle; (4) sleep deprivation that alters immune function; and (5) lower vitamin D and harmful lifestyle factors. ${ }^{3}$

\section{Clinical Scenario}

A 60-year-old man, came to a urology clinic in type A hospital, he complained about frequency of micturition, urinary urgency, and hesitancy associated with a weak stream, also not feeling satisfied in the end of miction. Examination for vital's signs were in normal range, but the rectal examination revealed a slightly enlarged prostate.

Patient then underwent some further investigations such as prostate-specific antigen (PSA), routine haematology, routine urinary, renal and liver function. The result for PSA level was $10 \mathrm{ng} / \mathrm{ml}$ (normal range $0,0-4 \mathrm{ng} / \mathrm{ml}$ ), haemoglobin level 15g/dl (normal range 13,2 - 17,1 g/dl), haematocrit $43 \%$ (normal range 38,5-50\%), white blood cell count $8.000 / \mathrm{mm}^{3}$, platelets $250.000 / \mathrm{mm}^{3}$, creatinine $1,0 \mathrm{mg} / \mathrm{dl}$ (range $0,5-1,4 \mathrm{mg} / \mathrm{dl}$ ), liver function AST $18 \mu / \mathrm{l}$ and ALT $21 \mu / 1$ (normal). Suggested inpatient and then underwent some imaging examination such as a transrectal ultrasonography revealed many hypoechoic areas within the homogenous parenchyma of the gland. Chest X-Rays and abdominal CT Scan were not found a process of metastasis.

Patient underwent a radical retropubic prostatectomy and the sample was examined at the pathological anatomy laboratory. The result showed an adenocarcinoma involving approximately 


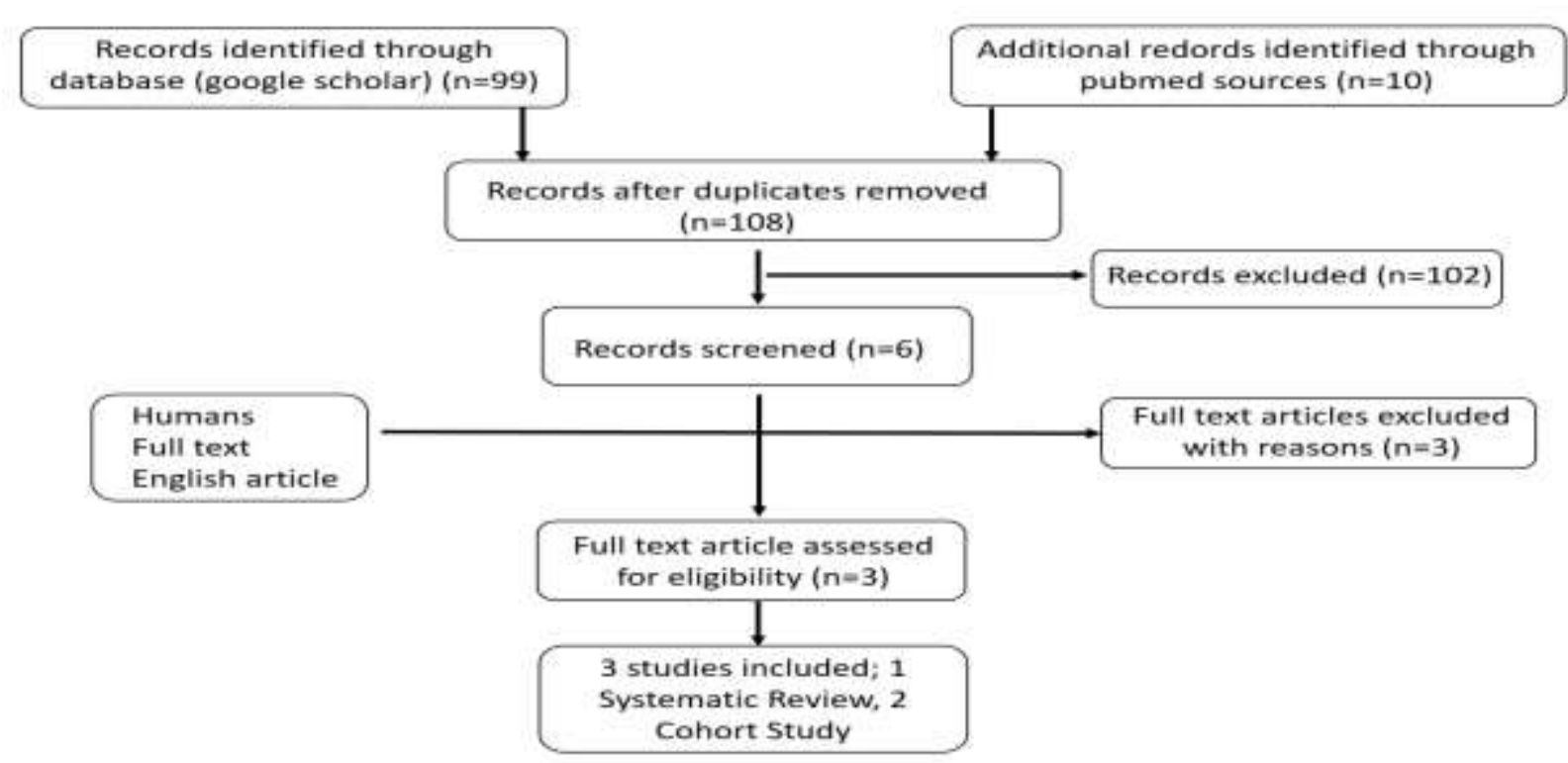

$60 \%$ of the gland, established capsule penetration and right seminal vesicle involvement and showed that a metastatic process to one of five lymph nodes.

Patient was discharged from the hospital after 10 days of treatment, and three months after surgery, patient's PSA was normal.

History of patient's work that he worked as an operator for CNC (Computer Numerical

Control) machine in a manufacture company for about 30 years, and retired 2 years ago. For his 30 years of working as an operator, he usually got night shifts for 10 12 hours (6 pm - 6 am) every shift and worked for 4 days consecutively. After 4 days of night shift, he got off duty for 3 days and then came to the other shift for 5 days consecutively from $6 \mathrm{am}-6 \mathrm{pm}$.

This patient asked whether his illness was related to his job, because there was no history of any malignancy in his family.

\section{Methods}

Literature searching strategies for answering the clinical question was made by May $6^{\text {th }} 2019$ used electronic database in Pubmed and Google Scholar. Key words which have been used were "shift work" "shift work schedule" "prostate cancer" which previously used the MeSH terms in both search engines and combined with Boolean operation "OR" and "AND". The inclusion criterias of this searching strategy were research in humans, full text article available, and language in English. The exclusion criterias of this article were inaccessible articles.

The selected articles were then critically appraised to determine whether the article is valid, important and applicable to the patient using relevant criteria for etiological study by the Oxford Center for Evidence-based Medicine. 
The Critical Appraisal and Result of

\section{Studies}

From the online search results, there were three selected articles that fit the inclusion and exclusion criteria: A systematic review by Mancio J. et al (2018); a cohort prospective study by Behrens $\mathrm{T}$. et al (2017); and a cohort prospective study by Torbjrn A. et al (2017).

Rapid Critical Appraisal of a Systematic Review by Mancio J. et al $2018{ }^{6}$

\section{Does the systematic review address a focused question (PICO)?}

P: Male worker in manufacturing industrial, I: Shift work, C: Non Shift work, O: Prostate Cancer

Result of critical $\quad$ Yes

appraisal

....and use it to direct the search and select article for inclusion?

Result of critical Yes

appraisal

Did the search find all the relevant evidence?

Result of critical Yes

appraisal

Have the studies been critically appraised?

Result of critical Unclear

appraisal

...and was the overall quality adequate?

Result of critical Yes

appraisal

Have the results been synthesised with appropiate summary tables and plots?

Result of critical Yes

appraisal

....and were the results similar between studies?

Result of critical Yes

appraisal

Rapid Critical Appraisal of a Cohort Study Etiology.

\begin{tabular}{|l|l|l|}
\hline & Behrens T. et al (2017) & Torbjrn A. et al (2017) $^{4}$ \\
\hline $\begin{array}{l}\text { Were there clearly defined } \\
\text { groups of } \\
\text { patients, similar in all } \\
\text { important ways } \\
\text { other than exposure to the } \\
\text { treatment or } \\
\text { other cause? }\end{array}$ & Yes & \\
\hline $\begin{array}{l}\text { Were treatment exposures } \\
\text { and clinical } \\
\text { outcomes measured the same } \\
\text { ways in } \\
\text { both groups? }\end{array}$ & Yes & \\
\hline
\end{tabular}




\begin{tabular}{|l|l|l|}
\hline $\begin{array}{l}\text { Was the follow-up of study } \\
\text { patients } \\
\text { complete and long enough? }\end{array}$ & Yes & Yes \\
\hline $\begin{array}{l}\text { Is it clear that the exposure } \\
\text { preceded the onset of the } \\
\text { outcome? }\end{array}$ & Yes & Yes \\
\hline $\begin{array}{l}\text { Is there a dose-response } \\
\text { gradient? }\end{array}$ & $\begin{array}{l}\text { Yes, related with duration } \\
\text { of employment in shift or } \\
\text { night work }\end{array}$ & $\begin{array}{l}\text { Not related with dose- } \\
\text { response gradient }\end{array}$ \\
\hline $\begin{array}{l}\text { Is there positive evidence } \\
\text { from } \\
\text { a } \square \text { dechallenge-rechallenge } \\
\text { study? }\end{array}$ & Not applicable & Not applicable \\
\hline $\begin{array}{l}\text { Is the association consistent } \\
\text { from study to study? }\end{array}$ & Yes & Yes \\
\hline $\begin{array}{l}\text { Does the association make } \\
\text { biological sense? }\end{array}$ & Unclear & Unclear \\
\hline
\end{tabular}

From the article by Mancio J. et al (2018), its said the most recent meta-analyses examining the association between nightshift work and prostate cancer yielded an increased risk of prostate cancer among nightshift workers, with summary relative risk (RR) estimates ranging between 1.08 and 1.24. These apparently conflicting findings could result from heterogeneity between studies, which may be explained not only by differences in the study design and characteristics of the participants, but also by different night-shift work definitions and schedules, such as fixed and rotating shift work. A systematic review and meta-analysis by Mancio $\mathrm{J}$. et al in 2018 was conducted according to the Preferred Reporting Items for Systematic Reviews and Meta-analysis statement and which assessed from nine studies. Searched previously from MEDLINE for studies assessing the association of night-shift work, in which the exposure was clearly defined as rotating and/or fixed night-shift work and the association of with prostate cancer, and based on study from Borrugian et al (2005) that compared the melatonin levels between rotating-shift workers and fixed shift workers in which its levels were lower and less variable in rotating night- shift workers while the decreased levels of melatonin during sleep are possibly related with increasing risk of cancer.

Studies that meet the criteria in this systematic review and meta-analysis were: (1) observational studies with cohort or case-control design; (2) one of the exposures being clearly defined as rotating or fixed night-shift work; (3) prostate cancer as the dependent variable, and (4) studies providing adjusted effect size estimates with their $95 \%$ confidence intervals(CIs), or data to calculate them by rotating or fixed nightshift work.

Statistical analysis; this review calculated pooled RRs and their 95\% CIs to assess the effect of night-shift work by rotating and fixed schedule on prostate cancer with using the inverse variance method. Publication bias was assessed through visual inspection of funnel plots. Heterogeneity between studies estimates was assessed using the $\mathrm{I}^{2}$ statistic, the model variables that may contribute to explain heterogeneity. These analyses were conducted separately for the association between fixed and rotating night-shift schedules. Then conducted a metaregression analyses for a formal comparison between the summary RR 
estimates referring to rotating or fixed night-shift work schedule, among the studies that provided data for both exposures.

For the result; Four studies provided information on associations of rotating and fixed night-shift work with prostate cancer risk in comparison with daytime work, and five studies provided information on association of rotating night-shift and prostate cancer only. Accordingly, a total of $120,319(4.8 \%)$ participants worked on a rotating scheme and $93,455(3.7 \%)$ on a fixed night-shift schedule. Overall, 9219 cases of prostate cancer were included. There was a significantly increased risk of prostate cancer with rotating (RR of 1.06, $95 \% \mathrm{CI}$ of 1.01 to $1.12 ; \mathrm{I}^{2}=50.2 \%$ ), but not with fixed night-shift work (RR of 1.01, $95 \%$ CI of 0.81 to $1.26 ; I^{2}=33.3 \%$ ). When comparing the summary RR for rotating and fixed schedule through metaregression, obtained result a summary RR $20 \%$ higher for rotating schedule. BMI and smoking did not affect to summary RR and the heterogeneity between studies, and if the confounding factor of smoking is really well controlled, the relationship between rotating night-shift work and prostate cancer is more strongly related (RR of 1.10 , $95 \% \mathrm{CI}$ of 0.99 to $1.21 ; \mathrm{I}^{2}=42,7 \%$ )

The cohort studies by Behrens T. et al. (2017) was conducted in Germany has an objectives to investigate the association of shift and night work with the incidence of prostate cancer using data of the population-based Heinz Nixdorf Recall Cohort Study (HNR) from the Ruhr area in Germany. The HNR is a population-based cohort study involving a random sample of 45-74 year-old. Participants for the baseline survey were recruited from 20002003 and a follow-up survey was conducted from 2011-2014. Agreement of questionnaire-based incident cancer cases with medical records and by recommendation from IARC working group was evaluated for an 8-year followup. This study has 1757 men with informations on shift and night work could be analyzed after excluded women, men with prostate cancer at baseline, men who did not participate in follow up interview, men without shift work information in follow up interview. Shift work was defined as any regular employment in shift systems including work hours outside 07:00-18:00 hours, whereas night work was defined as a shift that included work between 24:00-05:00 hours following recommendation by an IARC working group.

The author divides the shift work and night work categories in the analysis; (1) ever shift work ( $\geq 1$ year), (2) ever night work ( $\geq 1$ year), (3) duration of shift work, and (4) duration of night work. Job periods involving shift work after baseline were not considered in the analysis.

This study performed Cox proportional hazards regression analysis with age at event as timescale to determine the association between shift work before baseline and prostate cancer incidence. The other factors which took effect with prostate cancer in this study were age, preferred mid-point of sleep during off work $(<02: 30-03: 00$ hours for the early, 02:30-04:00 hours for the intermediate, and $>03: 30-04: 00$ hours for the late preference), body mass index, family history of prostate cancer, smoking status, alcohol consumption, vitamin D status, and education as the variables.

This study observed 76 incident primary prostate cancer cases during follow-up. The mean age at prostate cancer diagnosis was 66.8 years with standard deviation (SD) 6.83. Among men without prostate cancer mean age was 77.3 years (SD 7.18) at the time of interview. At follow-up, 106 men without prostate cancer were $\geq 80$ years (age at interview), whereas only 1 subject was $\geq 80$ years at age of prostate cancer diagnosis. There are $34 \%$ of men reported a history of shift work, and $27 \%$ of men with a history of night work.

Authors observed a twofold increased HR among shift workers (HR $2.29,95 \%$ CI 1.43-3.67) and night workers 
(HR 2.27, 95\% CI 1.42-3.64) both working in industries or in public services. Subjects who employed for $\geq 20$ years in shift or night work was associated with three- to fourfold increased risks (HR $3.0895 \%$ CI 1.67-5.69 and HR 3.76, 95\% CI 2.04-6.93, respectively). The analysis of men employed in shift work never entailing night work also showed slightly smaller HR. The confounding factors did not change the result significantly especially for status vitamin $\mathrm{D}$ no differences in prostate cancer risk due to shift or night work. Stratification by preferred midpoint of sleep revealed a trend with shift- and night-work duration particularly for the early sleep preference with HR increasing $>2$ times on subjects who work more than 1 year shift work or night work, and become smaller HR for intermediate and late sleep preferences respectively although the HR value remains more than 1 .

The cohort studies by Torbjrn A. et al (2017) was conducted in Sweden has an objective to investigate the prospective relation between number of years with night work and prostate cancer in men. The design was a prospective cohort study and was based on a previous study which was investigated the association of night shifts and breast cancer in women. Each individual participated in this study using computer-assisted telephone interview between 1998 and March 2003 with the total sample encompassed 12.322 men and followed up until 31 Desember 2010. From this total, 4816 male responders had been exposed to night work and 7506 male are non-night workers. The interview included questions on the duration of night work and a number of items regarding different diseases and symptoms. The individuals were followed prospectively from the interview response date. Data on incident cancer were obtained from two registers at the Swedish Cancer Registry and from the Cause of Death Register.

The exposed group was constituted of those who had worked at night for 1-45 years with the following categorisation was used: 1-5, 6-10, 11-20 and 21-45 years. Prostate cancer was defined as having at least one incident cancer diagnosis after the date of the interview, either according to the Swedish Cancer Registry or to the Cause of Death Register. The other variable used in this study were educational level, tobacco use, alcohol use, physical activity, BMI, have children, coffee use and previous cancer at the time of interview obtained result 187 men were non-night workers and 100 men were night workers.

The differences between day and night workers were tested by $\chi^{2}$ test for categorical variables and t-test for continuous variables. People with missing information were excluded in the analyses. Multiple Cox proportional hazard regression analyses for covariates were used to compute HRs with $95 \%$ CIs.

The mean follow-up time was 8.7 years (range: 0-13). Prostate cancer occurred in 454 men during follow up with the history of duration of exposure is 1 to 45 years (160 men exposed to night work with average of time to prostate cancer diagnosis was 5.8 years and 294 men with non-night worker with average of time to prostate cancer was 6.1 years) between baseline and the last day of the complete follow-up. The incidence was higher in the group with the highest exposure. Results of the Cox regression analyses did not show any significant association to prostate cancer after adjustment for covariates. No association with duration of night work was seen.

\section{Discussion}

The increased risk of prostate cancer occurs in the working population who work with shift work schedule, including night shift work that has a non-permanent pattern or with rotation. There is 1 study discussed here which shows insignificant results between ever night work and prostate cancer, nor for duration of night work and prostate cancer. The explanation was may be due to a lack of a common exposure 
measurement, no data available for differences in the type of or heterogeneous occupational groups involved in this study.

Of the three articles discussed, all of them have validity, importance and applicability value, but the article by Torbjrn does not apply to patient in the scenario. The validity, importance and applicability of the Systematic review by Mancio J. et al assessed from; (1) the inclusion and exclusion criteria in these studies are clearly defined; (2) the authors have performed a comprehensive search for all relevant studies using the Medline database and clearly mentioned keywords to identify and retrieve all potentially relevant articles regarding the topic; (3) this study show directly the RR values describes the association between night-shift work and prostate cancer differ according to rotating and fixed schedule; (4) there are the results of the same studies which show a significantly increased risk of developing prostate cancer in a population with a rotating night shift work pattern, and control for confounding factors were carried out. However, the limitation is none of the studies is critically appraised and did not describe clearly how the quality of each study was assessed.

Validity, importance and applicability value from the study by Behrens T. et al were assessed from; (1) the clarity of the research group division (never shift work and ever shift work including night work) of employees which were included a detailed phase-by-phase of the shift work history and night work following recommendation by an IARC working group with the same treatment in both groups; (2) the follow-up of study patients are complete and long enough; (3) the Hazard Ratio (HR) increased steadily with duration of employment in shift or night work and this association is consistent from several recent studies that have been published; (4) the population that works with shift work has the potential for a prostate cancer to occur with no time limit and if shift work is removed, the risk of prostate cancer continues. The relationship between exposure and outcome was strong, there was twofold increased HR for prostate cancer where ever employment in shift work was associated with HR 2.29, 95\% confidence interval (CI) 1.43-3.67 and night work with HR 2.27 , 95\% CI $1.42-$ 3.64. Patients in this scenario were included in the inclusion criteria according to a study by Behrens et al, in which the patient's risk of developing prostate cancer is based on calculations of NNH (Number Needed to Harm) from PEER (Patient's Expected Event Rate). The PEER was taken from other journal published by Kubo Tatsuhiko et al in 2006, and obtained result 4,896. This result mean from five subjects who work with shift work there is one subject who has prostate cancer. However the limitation from this study is the number of incident cases was small, stratified analyses by duration of shift or night work could not be performed in all subgroups, and the numbers of subjects in subgroups were small therefore the results tended to show wide confidence intervals. Then, the authors assessed the incidence of prostate cancer prospectively from the baseline interview, whereas the symptoms of prodromal prostate cancer such as nocturia may have been preexisting where the subject could be affected by sleep patterns and subsequently influenced his shift work choices. The operational definition of shift work in this study takes the definition recommended by the IARC, but cannot classify different shift schedules from each subject such as the number of days off after shift work or shift rotation schedules and other jobs that take time outside the work limit shift according to the IARC that can affect the sleep time of the subject, authors only classify the quality of shift work in terms of years.

Validity value from the study by Torbjrn A. et al were assessed from the two groups in this research was defined clearly and received the same treatment, being followed up with interviews and monitoring of research subjects was quite 
long and completed. However, it has no importance and applicability to the patient in the scenario because this research showed no association between ever night work and prostate cancer, nor for duration of night work and prostate cancer. This is in line with the 9 previous studies discussed in this study, where 6 studies failed to associate night work with prostate cancer, but the last 3 studies did show a significant association for ever night work and prostate cancer. The authors have provide the reasons, this discrepancy may be due to a lack of a common exposure measurement such as not measuring the change in the length of shift work that is different from the baseline data, no data available for differences in the type of or heterogeneous occupational groups involved, and selection into and out of night work occurs continuously may attenuate any associations. So that, there is clearly a need for further studies on this topic.

Neither of the two articles has discussed the pathophysiology of prostate cancer due to shift work in detail.

\section{Conclusion}

These studies show that, when compared with the daytime workers, in men who work with shift work including night work schedule was associated with a significantly increased risk of prostate cancer.

\section{Refferences}

1. Dana K.Mirick, Parveen Bhatti, Chu Chen, et al. Night Shift Work and Level of 6-Sulfatoxymelatonin and Cortisol in Men. Cancer Epidemiol Biomarkers Prev; 22(6); 1079-87. 2013.

2. Thomas Behrens, Sylvia Rabstein, Katharina Witchert et.al. Shift Work and the Incidence of Prostate Cancer: a 10-year follow-up of a German population-based cohort study. Scand J Work Environ Health; 43(6):560-568. 2017.

3. Lara G. Sigurdardottir, Unnur A. Valdimarsdottir, Lorelei A. Mucci et.al. Sleep Disruption Among Older Men and Risk of Prostate Cancer. Cancer Epidemiol Biomarkers Prev; 22(5). 2013.

4. Torbjrn Akerstedt, Jurgita Narusyte, Pia Svedberg et.al. Night Work and Prostate Cancer in Men: a Swedish prospective cohort study. BMJ Open; 7:e015751. 2017.

5. Meyomo G.W.F, Virginie Bayon, Sylvie Cenee et.al. Night Work and Prostate Cancer Risk: Results from the EPICAP Study. Occup Environ Med; 75:573-581. 2018.

6. Jennifer Mancio, Catia Leal, Marta Ferreira, Pedro Norton, Nuno Lunet. Does the Association of Prostate Cancer with Night-shift Work Differ According to Rotating vs. Fixed Schedule? A Systematic Review and Meta-analysis. Macmillan Publishers Limited. 2018.

7. Tatsuhiko Kubo, Kotaro Ozasa, Kazuya Mikami, et al. Prospective Cohort Study of the Risk of Prostate Cancer among Rotating Shift Workers: Findings from the Japan Collaborative Cohort Study. 